\title{
The Impact of Leadership Style, Motivation, and Teacher Work Discipline on Teacher Performance at MTs Negeri 2 in Palembang City
}

\author{
Erham Syarif $^{*}$, Happy Fitria ${ }^{2}$, Achmad Wahidy $^{2}$ \\ ${ }^{1}$ MTs Negeri 2 Palembang, South of Sumatera, Indonesia \\ ${ }^{2}$ Universitas PGRI, Palembang, Indonesia \\ *Corresponding author. Email: erhamsyarifman3@gmail.com
}

\begin{abstract}
The study's goal is to determine whether madrasah principals' leadership styles, motivation, and teacher work discipline have an effect on teacher performance in the Mts Negeri 2 Palembang Region. This study's tool is descriptive quantitative, with a survey methodology, data collection methods to determine the population, and a single sample of 60 teachers drawn from a population of 92. Multiple linear regression with simultaneous and partial experiments is used in the data analysis methodology. The findings of this study show that hypothesis testing (H1) has shown that there is an influence between the leadership style of madrasah principals and teacher performance, as follows: 1) the leadership style variable of madrasah principals has a significant influence on teacher performance variables, and 2) the motivation variable has a significant influence on teacher performance variables.
\end{abstract}

Keywords: Leadership Style, Motivation, Discipline, Performance

\section{INTRODUCTION}

According to Ratna Dewi's previous study, there is an effect of leadership style on teacher performance, the correlation coefficient is 0.647 , and each addition of the smallest amount of force would improve employee performance by 64.7 percent.

The results of research conducted by Siswoyo Haryono and Yasir Arafat with the title "Effects of Organizational Culture and Work Motivation on Job Performance Among the Private / Jniversities" Full-time Faculties in South Sumatra Province ". The verification results for hypothesis 2 reveal the relationship between work motivation and organizational commitment seen from the $t$ value and the probability value which shows that there is a significant and positive relationship between work motivation and organizational commitment with a significant value $(0.00<0.05)$.

Based on preliminary observations, it is known that the inadequate performance of MTs Negeri 2 Palembang teachers can be seen from the leadership of the madrasah principal who is still not maximal in involving teacher participation and some teachers whose performance is less than optimal in completing assignments at madrasah, the lack of awareness of teachers in completing work, there is a lack of teacher obedience to madrasah regulations, the available resources are still inadequate so that it has an impact on madrasah performance, there are still some teachers who do not have the will to create varied learning, there is still low work performance obtained by teachers, this shows that there are no teachers who get achievements as outstanding teachers at provincial and national levels, and lack of teacher commitment to the completion of a job so that the results of the job are not good.

According to the description above, determining the impact of leadership style, motivation, and work discipline on performance can be accomplished through research titled "The Effect of Madrasah Principals Leadership Style, Motivation, and Teacher Work Discipline on Teacher Performance in MTS Negeri 2 Palembang City".

A leader's leadership style is how he or she interacts with their subordinates [1]. From the study of leadership style theory above, It can be inferred that leadership style refers to the ability to manipulate a group to achieve specific goals, or that leadership is characterized as an action that influences the actions of others in general.

The principal is a determinant of success in the organization of a Madrasah based on what is expected, the duties and functions are very heavy, so that good is needed with the stakeholders who are in the scope of education, in order to achieve the desired goals together. The implementation of daily tasks must be accompanied 
by a clear vision and mission as the first step in running an organization [2].

Job discipline, according to this concept, is an attitude and action that demonstrates employee adherence to organizational regulations. The true aim of collective and individual discipline is to guide actions toward a harmonious reality. To establish these conditions, there must first be harmony between employees' rights and obligations / employees' rights and obligations.

In essence, teacher performance is described as a teacher's actions in producing and carrying out duties as an educator and teacher in the classroom in accordance with predetermined criteria [3]. Teacher output is a teacher's ability to carry out learning activities, from preparation to evaluating learning outcomes, and its achievement is dependent on the ability to carry out responsibilities as a teacher [4].

In an effort to improve teacher performance, the role of the head of the madrasah as a leader is very important. The success or failure of an objective achieved by madrasah depends on the leadership of the madrasah principal. Therefore, the factors that support the achievement of teacher performance, one of which is the leadership style of the head of the madrasah [5].

The principal's leadership has a positive impact on teacher success. The skill of an individual that emerges from within a teacher to be able to carry out his duties professionally within a certain timeframe is referred to as the teacher's success [6]. Argues that performance is the performance shown by a teacher through attitudes and behavior and work performance in order to achieve educational goals [6].

Teacher output is a collection of behavioral devices shown by an individual during the learning process, as well as a summary of the behaviors performed by a person while learning [7]. Teacher output, according to Baharudin [7], is a collection of behavioral devices shown by an individual during the learning process, as well as a description of the acts a person takes while learning.

An employee's performance is the product of his or her actions in carrying out tasks in accordance with the duties assigned to him or her [8]. The performance of a process of close, continuous reciprocal relations, partnerships between employees and leaders, understanding of the content of work, responsibility for work, carry out effective work.

Teacher success refers to a teacher's ability to carry out learning activities, from preparation to evaluating learning outcomes, the achievement of which is based on the ability to carry out obligations as a teacher [3].

In this case, teachers who carry out work at educational institutions are required to have these qualifications that guarantee expertise, proficiency or proficiency as professional educators. These mandatory criteria are quality standards that must be met by teachers. Professional teachers who meet these standards are a supporter of the creation of a quality person. teachers in carrying out their work. In order to carry out their profession, the teaching staff, especially in this case the teacher really needs a variety of knowledge [9].

The aim of this study was to see how the principal's leadership style, encouragement, and work discipline affected the performance of teachers at MTs Negeri 2 Palembang City.

\section{METHODS}

This research was conducted at MTs Negeri 2 Palembang City, and this research was conducted in the odd semester 2020-2021 academic year. When the research was conducted in July 2020, the quantitative approach was used in this analysis. Methodology determines the value of writing scientific articles [10]. This method can be used if the researcher wants to know the effect or treatment of others.

Based on the above, the population in this study consisted of all 73 teachers from MTs Negeri 2, consisting of 12 men and 61 women. Argues that if the population size is more or less than 100 , then the sampling is at least $50 \%$ of the population size. then the number of samples taken is $65 \%$ or 60 people randomly. 


\section{RESULTS AND DISCUSSION}

Table 1. Simultaneous Test $X_{1}, X_{2}, X_{3}$ on $Y$ Coefficientsa

\begin{tabular}{|c|c|c|c|c|c|c|c|c|}
\hline & \multirow{2}{*}{ Model } & \multicolumn{2}{|c|}{$\begin{array}{l}\text { Unstandardized } \\
\text { Coefficients }\end{array}$} & \multirow{2}{*}{$\begin{array}{c}\begin{array}{c}\text { Standardized } \\
\text { Coefficients }\end{array} \\
\text { Beta } \\
\end{array}$} & \multirow[t]{2}{*}{$\mathrm{T}$} & \multirow[t]{2}{*}{ Sig. } & \multicolumn{2}{|c|}{ Collinearity Statistics } \\
\hline & & $\mathrm{B}$ & Std. Error & & & & Tolerance & VIF \\
\hline \multirow{4}{*}{1} & (Constant) & 48.007 & 10.895 & & 4.406 & .000 & & \\
\hline & $\mathrm{X} 1$ & .524 & .150 & .503 & .3 .499 & .001 & .985 & 1.015 \\
\hline & $\mathrm{X} 2$ & .260 & .095 & .296 & 2.736 & .008 & .981 & 1.019 \\
\hline & $\mathrm{X} 3$ & -.716 & .152 & -.728 & -.4 .713 & .000 & .990 & 1.010 \\
\hline
\end{tabular}

a. Dependent Variable: Y

Based on data analysis using SPSS 22, the regression equation constant value $\alpha$ is 48.007 and the coefficient value of the independent variable $b 1$ is 0.524 , b2 is 0.260 and. b3 of 0.716 Then the calculation of the regression equation is as follows:

$$
\begin{aligned}
& Y=a+b_{1} X_{1}+b_{2} X_{2}+b_{3} X_{3} \\
& Y=48.007+0.524 X_{1}+0.260 X_{2}+0.716 X_{3}
\end{aligned}
$$

This suggests that the headmaster's leadership style, inspiration, and job discipline have impacted teacher success positively.

Table 2. Determination Test $X_{1}, X_{2}, X_{3}$ on $Y$

\section{Model Summary}

\begin{tabular}{|c|c|c|c|c|}
\hline Model & $\mathrm{R}$ & $\begin{array}{c}\mathrm{R} \\
\text { Square }\end{array}$ & $\begin{array}{c}\text { Adjusted R } \\
\text { Square }\end{array}$ & $\begin{array}{c}\text { Std. Error of the } \\
\text { Estimate }\end{array}$ \\
\hline 1 & $.694^{\mathrm{a}}$ & .482 & 454 & 3.240 \\
\hline
\end{tabular}

a. Predictors: (Constant), $\mathrm{X}_{1}, \mathrm{X}_{2}, \mathrm{X}_{3}$

According to the table above, the correlation coefficient is 0.694 or 6.94 percent, and the amount of impact can be seen from the Adjusted R Squre value of 0.454 or 4.54 percent, while the remainder is affected by other variables not previously investigated at 0.482 or 4.82 percent.

Inference The independent variable (independent) of the principal's leadership style $\left(\mathrm{X}_{1}\right)$ has a major influence on the dependent variable (dependent) teacher output (Y). This is evident from the results of multiple linear regression tests; in the regression test table, the significance value of 0.001 is less than 0.05 , implying that the principal's leadership style has a positive impact on teacher success.

Motivation is an independent variable (independent variable) $\left(\mathrm{X}_{2}\right)$ There is a major impact on the dependent variable (teacher performance) $(\mathrm{Y})$. The regression test table also indicates that the significance value of 0.008 is less than 0.05 , indicating that competence has a positive impact on teacher results.

The independent variable $\left(\mathrm{X}_{3}\right)$ job discipline has a major influence on the dependent variable $\left(\mathrm{X}_{3}\right)$ teacher output (Y). The regression test table also shows that the significance value of 0.000 is less than 0.05 , implying that competence has a positive impact on teacher results.

According to the regression test results, each independent variable of the principal's leadership style $\left(\mathrm{X}_{1}\right)$, motivation $\left(\mathrm{X}_{2}\right)$, and job discipline $\left(\mathrm{X}_{3}\right)$ has a significance value less than 0.05 , so it can be inferred that the three independent variables both have a meaningful or positive impact on the dependent variable on instructor (Y).

\section{CONCLUSION}

According to the regression test results, each independent variable of the principal's leadership style $\left(\mathrm{X}_{1}\right)$, motivation $\left(\mathrm{X}_{2}\right)$, and work discipline $\left(\mathrm{X}_{3}\right)$ has a significance value less than 0.05 , so it can be concluded that the three independent variables both have a significant or positive effect on the dependent variable on teacher performance (Y). That is, the better the madrasah principal's leadership, the better the teacher's performance; similarly, if the encouragement provided by the principal to the teacher is so good, the teacher's performance results would improve. 


\section{ACKNOWLEDGMENT}

Our deepest gratitude goes to Teachers in MTs Negeri 2 Palembang City, Chancellor of Palembang PGRI University, Director of the Postgraduate Program of PGRI Palembang University and the Education Management Study Program of PGRI Palembang University, who have supported us in doing this extraordinary thing. This project is funded independently. We also want to thank our Education Management friends who helped us a lot in a short time frame to complete this project.

\section{REFERENCES}

[1] Susanto, A. (2018). Concept, Strategy, and Implementation of Teacher Performance Improvement Management, Second Edition, Depok: Prenadamedia group.

[2] Fitria, H. 2018. The Influence of Organizational Culture and Trust Through the Teacher Performance in The Private Secondary School in Palembang. International Journal of Scientific \& Technology Research, 7 (7).

[3] Rachmawati, Y. (2013). The Influence of Principal Leadership on Teacher Performance, Volume 1. Journal of Economics Education Student at IKIP Veteran Semarang.

[4] Andriani, S., Kesumawati, N., \& Kristiawan, M. (2018). The Influence of the Transformational Leadership and Work Motivation on Teachers Performance. International Journal of Scientific \& Technology Research, 7(7).

[5] Imansyah, M., Yasir Arafat, \& Dessy Wardiah. 2020 The Effect of Principal Leadership and School Committee Participation on Teacher Performance. Journal of Management, Leadership and Educational Supervision. Vol 5, No. 2

[6] Mulyasa. (2004). Being a professional teacher creates creative and fun learning. Bandung: Rosdakarya.

[7] Ngiode, S. (2016). The Influence of Principal Leadership, Work Motivation and Work Discipline on Teacher Performance at MTs.N Batudaa, Gorontalo District. Volume 4. Journal of Islamic Education Management.

[8] Arafat, Y., \& Haryono, S. (2017). Effects of Organizational Culture ang Work Motivation on Job Performance Among the Private University Fulltime Fakulties in South Sumatra Province. (X2) volume 20. International Information Institute. Master of Program Management, Post Graduate School, (Muhammadiyah University of Yogyakarta).

[9] Fitria, H., Kristiawan, M., \& Rahmat, N. (2019). Efforts to Improve Teacher Competence through
Classroom Action Research Training. ABDIMAS UNWAHAS, 4 (1).

[10] Muttaqin, K., \& Rahmadoni, J. (2020). Analysis and Design of File Security System AES (Advanced Encryption Standard) Cryptography Based. Journal of Applied Engineering and Technological Science (JAETS), 1(2), 113-123. https://doi.org/10.37385/jaets.v1i2.78 